\title{
PENGARUH MODEL PEMBELAJARAN KONTEKSTUAL TERHADAP KEMAMPUAN MEMBACA PERMULAAN ANAK
}

\author{
Putu Aditya Antara ${ }^{1}$, Putu Rahayu Ujianti ${ }^{2}$, Anggun La Patissera ${ }^{3}$ \\ 1,2,3 Universitas Pendidikan Ganesha \\ Singaraja, Indonesia \\ e-mail: putuaditya.antara@undiksha.ac.id', puturahayuujianti@undiksha.ac.id ${ }^{2}$, \\ anggun.la.patissera@undiksha.ac.id ${ }^{3}$,
}

\begin{abstract}
Abstrak
Penelitian ini bertujuan untuk Mengetahui Pengaruh Model Pembelajaran Kontekstual Terhadap Kemampuan Membaca Permulaan Anak Kelompok B Tk Gugus I Kecamatan Kuta Selatan. Jenis peneltian ini adalah penelitian eksperimen semu (quasi eskperiment) dengan rancangan Desain non equivalent post test only control group design. Populasi pada penelitian ini berjumlah 269 anak kelompok B TK Gugus I Kecamatan Kuta Selatan. Sampel pada penelitian ini diperoleh menggunakan teknik Simple Random Sampling. Metode pengumpulan data yang digunakan adalah metode pengumpulan data berupa observasi dan metode rubrik penilaian kemampuan membaca permulaan. Data yang dikumpulkan dianalisis dengan mengunakan analisis statistik deskriptif dan analisis inferensial. Analisis statistik inferensial menggunakan uji-t ditemukan nilai thitung 12,586 dengan $\mathrm{db}=34$ pada taraf signifikansi $5 \%$, sedangkan thitung $>$ ttabel. Sehingga ini dapat diinterpretasikan bahwa terdapat perbedaan yang signifikan antara kelompok anak yang memperoleh pembelajaran dengan model pembelajaran kontekstual dengan kelompok anak yang tidak memperoleh pembelajaran dengan model pembelajaran kontekstual terhadap kemampuan membaca permulaan anak.
\end{abstract}

Kata-kata kunci : Pembelajaran Kontekstual, Kemampuan Membaca Permulaan, Anak Kelompok B

\begin{abstract}
This research aim to knowing the effects of the contextual learning model on the ability to read the beginning of child group b of kindergarten group I sub-district South Kuta. This type of research is an experimental research pseudo (quasi-experiment) with a non-equivalent post-test only control group design. The population on this research is 269 child group b of kindergarten group I sub-district South Kuta. Sample on this research is obtained using technique Simple Random Sampling. The data collection method used is a data collection method in the form of observation and assessment rubric method read the beginning. Data collected analyzed with used descriptive statistics analysis and inferential analysis. Statistics inferential analysis used $t$ - test value obtained tcount 12,586 for $\mathrm{db}=34$ on significance level $5 \%$. while tcount $>\mathrm{t}$ table. So that this can be interpreted that there are significant difference between child group which obtains teaching by learning model contextual with child group is not obtain teaching by learning model contextual toward the ability to read the beginning of a child.
\end{abstract}

Keywords: Contextual Learning, Skill Read The Beginning, Group B Children 


\section{Pendahuluan}

Anak merupakan generasi penerus bangsa yang tidak ternilai harganya, sehingga untuk mendapatkan generasi penerus yang berkualitas tinggi maka fisik dan mentalnya harus dipersiapkan sejak dini dengan berbagai bentuk stimulasi. Stimulasi terhadap anak perlu dilakukan sedini mungkin baik berupa pengetahuan, fisik dan yang tidak kalah pentingnya adalah pembinaan mental sosial. Karena anak tidak akan pernah lepas dari kehidupan sebagai makhluk sosial yang selalu butuh berhubungan dengan orang lain. Pelaksanaan stimulasi bisa dilakukan berbagai lembaga pendidikan anak usia dini yang meliputi Taman Penitipan Anak (TPA), Kelompok Bermain (KB), dan Taman Kanak-kanak (TK). Pembentukan mental anak membutuhkan nilai-nilai karakter yang bisa dijadikan dasar berperilaku di dalam masyarakat khususnya TK, karena pada usia ini anak sudah akan mulai mengakhiri masa pra operasional yang ditunjukkan bahwa anak sudah bisa menerima kondisi akademik yang lebih komplek. Sehingga pada usia TK anak membutuhkan penanaman nilai karakter yang tepat agar anak bisa menginternalisasi nilai karakter dengan baik.

Menurut National Association for the Education of Young Children (NAEYC) menurut Brewer (2007 : 4), anak usia dini merupakan anak yang berada dalam rentang usia nol sampai dengan delapan tahun. Pada masa tersebut, anak mengalami proses pertumbuhan dan perkembangan yang pesat baik fisik maupun mental. Selain pertumbuhan dan perkembangan fisik dan motorik, secara simultan juga mengalami perkembangan moral (termasuk kepribadian, watak, dan akhlak), sosial, emosional, intelektual, dan bahasa yang amat pesat.

Pendidikan anak usia dini lebih mengutamakan proses pembelajaran yang terintegrasi karena anak memiliki berbagai potensi yang harus dikembangkan secara maksimal untuk berbagai kemampuan dalam memecahkan masalah kehidupannya di masa depan. Perkembangan anak yang dicapai merupakan integrasi aspek pemahaman nilai-nilai agama dan moral, fisik, kognitif, bahasa, serta sosial-emosional (Direktorat Pendidikan Anak Usia Dini, 2009). Melihat berbagai hal yang perlu diperhatikan dalam proses pembelajaran anak, maka seorang guru harus bisa memahami setiap potensi yang akan dikembangkan sekaligus membuat kegiatan belajar yang semenarik mungkin untuk dilakukan anak dalam proses pembelajaran.

Kenyataan yang terjadi di masyarakat bahwa tanpa disadari semua perilaku serta kepribadian orang tua yang baik ataupun tidak ditiru oleh anak. Anak tidak mengetahui apakah yang telah dilakukanya baik atau tidak karena anak usia prasekolah belajar dari apa yang telah dia lihat. Pembelajaran tentang sikap, perilaku, dan bahasa yang baik akan membentuk kepribadian anak yang baik pula. Hal ini perlu diterapkan sejak dini. Orang tua merupakan pendidik yang paling utama, sedangkan guru serta teman sebaya merupakan lingkungan kedua bagi anak.

Dengan demikian, orang yang paling penting bagi anak adalah orang tua, guru dan teman sebaya karena dari merekalah anak mengenal sesuatu yang baik dan tidak baik (Hurlock, 1978). Berbagai hal yang anak pelajari dari lingkungannya merupakan potensi besar yang akan menjadi gambaran berbagai perilaku yang anak miliki dalam fase perkembangan selanjutnya.

Pembelajaran membaca permulaan erat kaitannya dengan pembelajaran menulis permulaan. Sebelum mengajarkan menulis, guru terlebih dahulu mengenalkan bunyi suatu tulisan atau huruf yang terdapat pada kata-kata dalam kalimat. Pengenalan tulisan beserta bunyi ini melalui pembelajaran membaca. Kemampuan membaca permulaan merupakan "Kemampuan membaca yang diperoleh pada membaca permulaan akan sangat berpengaruh terhadap kemampuan membaca lanjut. Jika pada membaca permulaan belum kuat, maka pada tahap membaca lanjut siswa akan mengalami kesulitan untuk dapat memiliki kemampuan yang memadai" (Darmiyati Zuchdi dan Budiasih, 1996/1997:50). 
Menurut Zuchdi Darmiyati dan Budiasih (1996/1997:50-51) membaca permulaan diberikan secara bertahap yakni: a) Pramembaca, pada tahap ini anak diajarkan: (1) sikap duduk yang baik, (2) cara meletakan / menempatkan buku di meja, (3) cara memegang buku, (4) cara membalik halaman buku yang tepat, dan (5) melihat / memperhatikan gambar atau tulisan. b) Membaca, pada tahap ini anak diajarkan: (1) lafal dan intonasi kata dan kalimat sederhana (menirukan guru), (2) huruf-huruf yang banyak digunakan dalam kata dan kalimat sederhana yang sudah dikenal anak (huruf-huruf diperkenalkan secara bertahap sampai pada 14 huruf).

Sabarti Akhadiah, dkk. (1992/1993:11) menyatakan, "Membaca permulaan ditekankan pada "menyuarakan" kalimat-kalimat yang disajikan dalam bentuk tulisan. Dengan kata lain, anak dituntut untuk mampu menerjemahkan bentuk tulisan ke dalam bentuk lisan. Dalam hal ini, tercakup pula aspek kelancaran membaca. Anak harus dapat membaca wacana dengan lancar, bukan hanya membaca kata-kata ataupun mengenali huruf -huruf yang tertulis".

Perkembangan ilmu pengetahuan dan teknologi menuntut terciptanya masyarakat yang gemar belajar membaca. Proses belajar efektif antara lain dilakukan melalui membaca. Membaca memiliki manfaat bagi kehidupan manusia. Manfaat membaca yaitu "mendapatkan informasi dari media visual (gambar tanda-tanda jalan) dan media cetak misalnya surat kabar" (Farida Rahim, 2008:1).

Pembelajaran kontekstual dapat diterapkan di kelas, hal ini sesuai dengan pendapat Depdiknas. "CTL pada dasarnya dapat diterapkan dalam kurikulum apa saja, bidang apa saja, dan kelas yang bagaimanapun keadaannya" (Trianto, 2008:25). Secara garis besar langkahlangkah penerapan CTL dalam kelas adalah sebagai berikut: Kembangkan pemikiran bahwa anak akan belajar lebih bermakna dengan cara bekerja sendiri, menemukan sendiri, dan mengkonstruksi sendiri pengetahuan dan keterampilan barunya, Laksanakan sejauh mungkin kegiatan ingkuiri untuk semua topik, Kembangkan sifat ingin tahu siswa dengan bertanya, Ciptakan masyarakat belajar (belajar dalam kelompok kelompok), Hadirkan model sebagai contoh pembelajaran, Lakukan refleksi di akhir pertemuan, Lakukan penilaian yang sebenarnya dengan berbagai cara. (Trianto, 2008:25-26)

Model pembelajaran kontekstual bukan merupakan suatu konsep baru. Penerapan model pembelajaran kontekstual di kelas-kelas Amerika pertama-tama diusulkan oleh Dawey pada tahun 1961, Dawey (dalam Sumiati dan Asra, 2009:14) mengusulkan suatu kurikulum dan metodologi pengajaran yang berkaitan dengan minat dan pengalaman siswa, sehingga muncullah berbagai teori mengenal model pembelajaran kontekstual.

Model pembelajaran kontekstual "sebuah sistem yang menyeluruh kontekstual terdiri dari bagian-bagian yang saling berhubungan. Jika bagian-bagian ini terjalin satu sama lain, maka akan dihasilkan pengaruh yang melebihi hasil yang diberikan bagian-bagiannya secara terpisah" (Jhonson, 2006:65).

Model pembelajaran kontekstual adalah "pembelajaran yang mengaitkan materi yang dipelajari dengan kehidupan nyata siswa sehari-hari, baik dalam lingkungan, keluarga, sekolah, masyarakat maupun warga negara dengan tujuan untuk menemukan makna materi tersebut bagi kehidupan" (Komalasari, 2010:7).

Suprijono (2009:79) menyatakan, "Model pembelajaran kontekstual merupakan konsep yang membantu guru mengaitkan antara materi yang diajarkan dengan situasi dunia nyata dan mendorong peserta didik membuat hubungan antara pengetahuan yang dimiliki dengan penerapan dalam kehidupan mereka sebagai anggota keluarga dan masyarakat. Pengetahuan dan keterampilan anak diperolah dari usaha anak mengkonstruksikan sendiri pengetahuan dan keterampilan baru ketika ia belajar".

Nurhadi (dalam Sugiyanto, 2010:13) mengatakan "Model pembelajaran kontekstual adalah konsep belajar mengajar yang mendorong guru untuk menghubungkan antara materi yang diajarkan dengan situasi dunia nyata anak. Jadi, untuk mendukung tahap model pembelajaran kontekstual menurut Nurhadi, maka digunakanlah suatu media nyata yang dapat membatu anak dalam mengenalkan huruf. 
Model pembelajaran kontekstual, Whitehead mengungkapkan "pentingnya sebuah pengetahuan terletak pada kegunaannya, pada penguasaan kita terhadap pengetahuan itu" (Alwasilah, 2009:31). CTL merupakan system yang bersifat menyeluruh. CTL melibatkan para siswa dalam aktifitas penting yang membantu mereka mengaitkan pelajaran akademis dengan konteks kehidupan nyata yang mereka hadapi. Dengan mengaitkan keduanya mereka menemukan makna, Penemuan makna ini adalah merupakan ciri utama dari CTL, karena CTL mengajak anak menemukan makna, CTL memiliki potensi untuk membuat anak berminat belajar Whitehead menegaskan tidak akan ada perkembangan mental tanpa adanya minat. Minat adalah "dasar dari perhatian dan pemahaman, ini berarti dengan menerapkan CTL anak dapat menemukan makna dari pembelajaran sehingga CTL memiliki potensi untuk membuat anak berminat dalam kegiatan pembelajaran tersebut, dengan minat yang ada dalam diri anak maka anak akan memperhatikan, sehingga anak akan paham dengan apa yang dipelajarinya" (Alwasilah, 2009:37).

Berdasarkan latar belakang diatas dapat dirumuskan permasalahan "Apakah terdapat perbedaan yang signifikan antara kelompok anak yang memperoleh pengajaran dengan model pembelajaran kontekstual dengan kelompok anak yang tidak memperoleh pengajaran dengan model pembelajaran kontekstual terhadap kemampuan membaca permulaan anak kelompok B di Taman Kanak-kanak Gugus I Kecamatan Kuta Selatan tahun pelajaran 2018/2019?".

Penelitian ini hanya dibatasi pada pengaruh model pembelajaran kontekstual terhadap kemampuan membaca permulaan anak kelompok B di Taman kanak-kanak gugus I kecamatan Kuta Selatan tahun pelajaran 2018/2019. Mengingat terbatasnya waktu, tenaga, biaya dan kemampuan peneliti, maka penelitian ini terbatas pada dua Taman kanak-kanak dari delapan Taman kanak-kanak yang ada di gugus I kecamatan Kuta Selatan, yaitu satu taman kanakkanak sebagai kelompok eksperimen dan satu taman kanak-kanak sebagai kelompok kontrol. Tujuan penelitian ini untuk mengetahui perbedaan yang signifikan antara kelompok anak yang memperoleh pengajaran dengan model pembelajaran kontekstual dengan kelompok anak yang tidak memperoleh pengajaran dengan model pembelajaran kontekstual terhadap kemampuan membaca permulaan anak kelompok B di Taman Kanak-kanak Gugus I Kecamatan Kuta Selatan Tahun pelajaran 2018/2019.

\section{Metode}

Penelitian ini dilakukan di Taman Kanak-Kanak Gugus I Kecamatan Kuta Selatan pada anak kelompok B. Jenis penelitian ini menggunakan eksperimen semu (quasi eksperimen) dengan rancangan Desain non equivalent post test only control group design. Secara prosedural desain penelitian ini disajikan dalam Tabel 1 berikut ini.

Tabel 1. Desain Penelitian Non Equivalent Control Group Design

\begin{tabular}{|c|c|c|}
\hline Kelompok & Perlakuan & Post-test \\
\hline $\begin{array}{l}\text { Eksperimen } \\
\text { Kontrol }\end{array}$ & $\begin{array}{c}X_{1} \\
-\end{array}$ & $\begin{array}{l}\mathrm{O}_{1} \\
\mathrm{O}_{2}\end{array}$ \\
\hline
\end{tabular}

Populasi dalam penelitian ini adalah semua anak kelompok B di gugus I Kecamatan Kuta Selatan. Pengambilan sampel pada penelitian ini menggunakan teknik Simple Random Sampling. Peneliti menggunakan teknik ini disebabkan populasi taman kanak-kanak gugus I kecamatan Kuta Selatan yang terdiri dari 8 Taman Kanak-kanak yaitu TK Taman Penta, TK Duta Kusuma, TK Kumara Sari 4, RA Insan Mulia, RA Al Ma'Arif, TK Dini Kumara, TK Lentera Hati, TK Tadika Puri . Dari 8 Taman Kanak-kanak ini akan diambil 2 Taman Kanak-kanak sebagai kelompok eksperimen dan kelompok kontrol. Suatu konsep yang sangat penting dalam penelitian disebut dengan variabel. Sesuatu yang dipilih oleh peneliti yang menjadi objek perhatian yang akan dipelajari oleh peneliti sehingga diperoleh informasi tentang hal tersebut 
kemudian ditarik kesimpulannya disebut variabel. Variabel penelitian ini dijelaskan bahwa terdapat dua variabel yaitu variabel bebas (model pembelajaran kontekstual) dan variabel terikat (Kemampuan Membaca Permulaan). Model Pembelajaran Kontekstual adalah cara guru memberikan pembelajaran dengan cara memberikan suatu materi atau cerita kepada anak murid dan mengaitkan materi tersebut di lapangan atau ke kehidupan sehari-hari. Jadi dengan model pembelajaran konteksual ini anak murid mendapatkan suatu pesan, ilmu, atau pengetahuan dengan cara yang mudah dimengerti oleh anak. Dalam penelitian ini akan digunakan metode pengumpulan data berupa Observasi dan Metode rubrik penilaian kemampuan membaca permulaan. a) Observasi adalah pengamatan dan pencatatan secara sistematis terhadap unsur-unsur yang tampak dalam gejala-gejala dalam objek penelitian. b) Metode Rubrik Penilaian merupakan panduan penilaian yang menggambarkan kriteria yang diinginkan guru dalam menilai atau memberikan tingkatan dari hasil perkerjaan siswa.

Teknik Pengumpulan data dengan Uji Validitas Dalam penelitian ini validitas isi diuji melalui expert judgement. Dalam hal ini 2 orang pakar diminta untuk menilai kesesuaian instrumen dengan isi variabel yang hendak diukur, kemudian hasil penelitian kedua pakar dianalisis dengan menggunakan teknik yang dikembangkan oleh Gregory (2011).

Data yang dianalisis dalam penelitian ini adalah data kemampuan membaca permulaan anak, dan untuk mendapat data tersebut digunakan teknik penilaian rubrik. Sebelum tes digunakan terlebih dahulu dilakukan mengujian instrumen yang meliputi:

Pertama uji validitas yang meliputi: (1) validitas isi berkenan dengan kesanggupan alat penilaian dalam mengukur cakupan substansi yang seharusnya. Artinya, instrumen tersebut mampu mengungkap isi variabel yang hendak diukur. (2) validitas butir ini dilakukan untuk mengetahui kebenaran setiap butir alat penilaian. Untuk mengukur validitas butir penilaian rubrik menggunakan rumus korelasi korelasi point biserial. Skor yang diperoleh kemudian

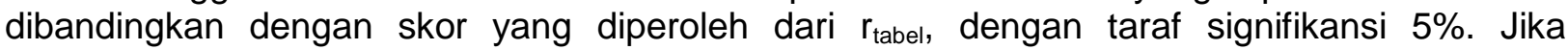
$r_{\text {hitung }}>r_{\text {tabel }}$ berarti valid dan jika $r_{\text {hitung }}<r_{\text {tabel }}$ berarti tidak valid. Dari 16 butir yang telah diuji cobakan maka diperoleh 16 butir yang valid.

Kedua, reliabilitas rumus yang digunakan adalah Kuder Richardson 20 (KR-20). Dari 16 butir dan hasil perhitungan reabilitas tes kemampuan membaca permulaan diperoleh $r 1.1=$ 0,84 itu artinya bahwa soal tes penilaian rubrik pada penelitian ini tergolong sangat tinggi.

Data hasil kemampuan membaca permulaan yang telah terkumpul dianalisis menggunakan uji-t. Sebelum dianalisis terlebih dahulu dilakukan uji prasyarat analisis data yaitu: (1) uji normalitas sebaran data untuk skor kemampuan membaca permulaan anak digunakan analisis uji Kolmogorov-Smirrnov test dan Shapiro-Wilk test dengan bantuan SPSS. Kriteria pengujian yang digunakan adalah data memiliki sebaran normal jika angka signifikansi yang dihasilkan lebih dari 0,5, (2) uji homogenitas varians, kriteria pengujian homogenitas varians jika $F_{\text {hitung }}>F_{\text {tabel }}$ maka kriteria pengujian homogenitas dikatakan homogen.

Uji hipotesis pada penelitian ini menggunakan uji-t dengan rumus separated varians. Dengan kriteria jika $t_{\text {hitung }}>t_{\text {tabel }}$ pada taraf signifikansi $5 \%$ dengan $d k=n_{1}+n_{2}-2$, maka $H_{0}$ diterima.

\section{Hasil dan Pembahasan}

Berdasarkan data kemampuan membaca permulaan, dianalisis menggunakan analisis statistik deskriptif agar dapat mengetahui mean, median, modus, standar deviasi, dan varians, dari data hasil post test pada kelompok eksperimen dan kelompok kontrol. Rangkuman hasil analisis data statistik deskriptif post test pada kelompok eksperimen dapat dilihat pada Tabel 2 sebagai berikut. 
Tabel 2. Deskriptif data post test kemampuan membaca permulaan kelompok eksperimen.

\begin{tabular}{cc}
\hline Statistik & Kemampuan Membaca Permulaan \\
\hline Mean & 42,94 \\
Median & 43,50 \\
Modus & 44,3 \\
Standar Deviasi & 2,60 \\
Varians & 6,76 \\
\hline
\end{tabular}

Kemudian, data kemampuan membaca pemulaan kelompok eksperimen disajikan ke dalam bentuk grafik histogram, seperti pada Gambar 1 sebagai berikut.

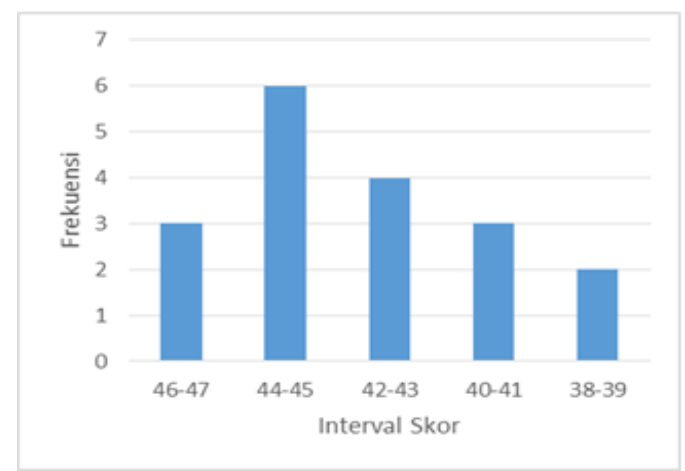

Gambar 1. Grafik Histogram Kemampuan Membaca Kelompok Eksperimen

Data kemampuan membaca permulaan post test kelompok kontrol disajikan pada Tabel 3 Sebagai berikut.

Tabel 3. Deskriptif data post test Kemampuan Membaca Permulaan kelompok kontrol.

\begin{tabular}{cc}
\hline Statistik & Kemampuan Membaca Permulaan \\
\hline Mean & 32,11 \\
Median & 31,16 \\
Modus & 30,83 \\
Standar Deviasi & 2,56 \\
Varians & 6,57 \\
\hline
\end{tabular}

Kemudian, data kemampuan membaca permulaan kelompok kontrol disajikan ke dalam bentuk grafik histogram, seperti pada Gambar 2 sebagai berikut. 




\section{Gambar 2. Grafik Histogram Kemampuan Membaca Kelompok Kontrol}

Dari data kemampuan yang sudah terkumpul dianalisis menggunakan uji-t. Sebelum dianalisis terlebih dahulu dilakukan uji prasyarat yang meliputi uji normalitas sebaran data dan uji homogenitas varians. Hasil analisis uji normalitas sebaran data post test kelompok ekperimen dan kelompok kontrol disajikan ke dalam Tabel 4 sebagai berikut

Tabel 4. Uji Normalitas Sebaran Data

\begin{tabular}{|c|c|c|c|c|c|c|}
\hline & \multicolumn{3}{|c|}{ 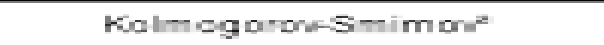 } & \multicolumn{3}{|c|}{ ShEpiru-iris } \\
\hline & Statistic & dif & Sigl- & Stafistic: & $\pm=$ & $\Xi g$ \\
\hline 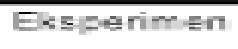 & $-15 \mathrm{a}$ & $7 \pm$ & 200 & $95 \mathrm{E}$ & $1 \mathrm{a}$ & $\equiv 71$ \\
\hline remtin & $-16 \mathrm{a}$ & 15 & -196 & 963 & $-1 \mathrm{a}$ & E6: \\
\hline
\end{tabular}

Berdasarkan Tabel di atas dapat dilihat pada Kolmogorov Smirnov dan Shapiro-Wilk dilihat pada taraf sig >0,05 dengan taraf signifiknsi 5\%, bahwa sebaran data pada kelompok eksperimen dan kontrol berdistribusi normal. Hasil analisis uji homogenitas varians post test kelompok ekperimen dan kelompok kontrol disajikan ke dalam tabel 5 sebagai berikut

Tabel 5. Uji Homogenitas Sebaran Data

\begin{tabular}{|c|c|c|c|c|c|}
\hline & & Leses & $a$ & de & sa \\
\hline \multirow{4}{*}{ Ensoperimen } & Elasedion Fean & $\operatorname{sen} 2$ & 1 & IE & 912 \\
\hline & Basted on Median & at: & 1 & $\exists=$ & 911 \\
\hline & Bayed an Median and & $01 \pm$ & 1 & 33 coses & 911 \\
\hline & Based an thimmed mean & ant & 1 & $3=$ & 914 \\
\hline
\end{tabular}

Berdasarkan data pada Tabel 5 diatas, menunjukkan bahwa dilihat pada Base on Mean pada Sig memiliki angka 0,912 signifikansi lebih besar dari 0,05. Maka dapat disimpulkan semua sebaran data kemampuan membaca permulaan sudah homogen. Setelah diperoleh hasil dari uji prasyarat analisis data, dilanjutkan dengan pengujian hipotesis penelitian. Pengujian hipotesis tersebut dengan menggunakan analisis uji-t. Sebelum melakukan analisis uji-t dilakukan analisis gain score dari data post test kemampuan membaca permulaan kelompok eksperimen dan kelompok kontrol. Ringkasan uji hipotesis disajikan pada Tabel 6 sebagai berikut. 
Tabel 6. Hasil Uji-t

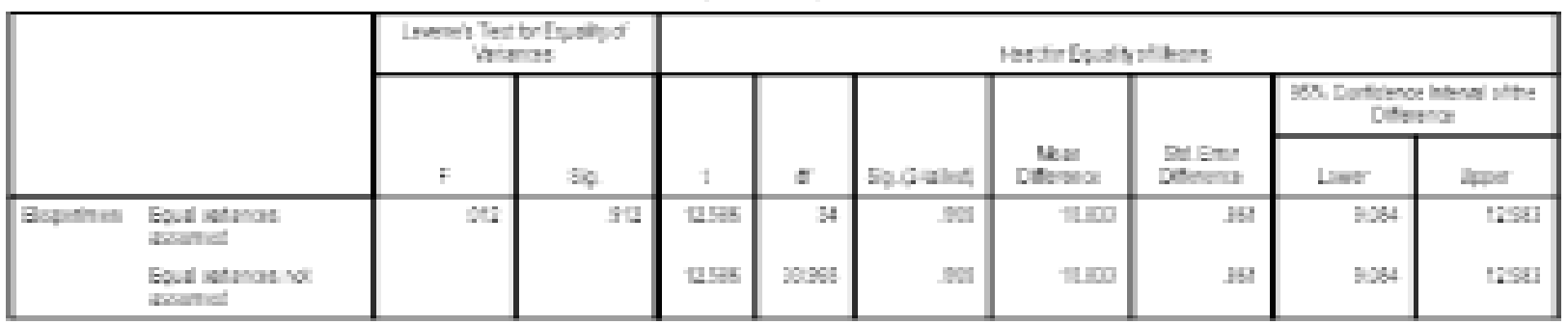

Berdasarkan data Tabel diatas, diperoleh $t_{\text {hitung }}=12,586$. Adapun nilai $t_{\text {tabel }}$ dengan taraf signifikansi $5 \%$ dan derajat kebebasan $\mathrm{dk}=18+18-2=34$ adalah 2,042. Dengan demikian nilai $t_{\text {hitung }}>t_{\text {tabel }}$ yang berarti $\mathrm{H} 0$ ditolak dan $\mathrm{H} 1$ diterima. Artinya, terdapat perbedaan yang signifikan antara kelompok anak yang memperoleh pengajaran dengan model pembelajaran kontekstual dengan kelompok anak yang tidak memperoleh pengajaran dengan model pembelajaran kontekstual terhadap kemampuan membaca permulaan anak.

Model pembelajaran kontekstual berpengaruh secara signifikan terhadap kemampuan membaca permulaan pada anak. Hal ini didukung secara empiris melalui penelitian eksperimen yang telah dilakukan. Berdasarkan hasil temuan pada kedua kelompok diperoleh jika kedua kelompok yang awalnya memiliki kemampuan setara, setelah diberikan perlakuan pada kelompok eksperimen maka nilai kemampuan membaca permulaan pada anak mengalami perbedaan yang signifikan. Kemampuan membaca permulaan pada anak kelompok eksperimen lebih baik apabila dibandingkan dengan kemampuan membaca permulaan pada anak kelompok kontrol. Hal ini dapat dilihat dari rata-rata skor kemampuan membaca permulaan anak pada kelompok eksperimen adalah 42,94, sedangkan rata-rata skor kemampuan membaca permulaan anak pada kelompok kontrol adalah 32,11.

Model pembelajaran kontekstual saat diterapkan dikelompok eksperimen guru memberikan pembelajaran dengan cara memberikan materi atau cerita kepada anak dan mengaitkan materi tersebut di lapangan atau ke kehidupan sehari-hari. Hal ini sesuai dengan pendapat Sanjaya (2006) "Model pembelajaran kontekstual adalah pembelajaran yang menekankan kepada proses keterlibatan anak secara penuh untuk dapat menemukan materi yang dipelajari dan menghubungkannya dengan situasi kehidupan nyata sehingga mendorong anak untuk dapat menerapkannya dalam kehidupan mereka".

Model pembelajaran kontekstual ini menerapkan konsep belajar yang membantu guru mengaitkan antara materi yang diajarkan dengan situasi dunia nyata yang mendorong siswa membuat hubungan antara pengetahuan yang dimilikinya dengan penerapan teori dalam kehidupan sehari-hari. Hal ini sejalan dengan pendapat Suprijono (2009) "Model pembelajaran kontekstual merupakan konsep yang membantu guru mengaitkan antara materi yang diajarkan dengan situasi dunia nyata dan mendorong peserta didik membuat hubungan antara pengetahuan yang dimiliki dengan penerapan dalam kehidupan mereka sebagai anggota keluarga dan masyarakat. Pengetahuan dan keterampilan anak diperoleh dari usaha anak mengkonstruksikan sendiri pengetahuan dan keterampilan baru ketika ia belajar".

Model pembelajaran kontekstual menekankan proses keterlibatan anak untuk menemukan materi. Prosesnya tidak mengharapkan anak hanya menerima pelajaran, akan tetapi ada proses mencari dan menemukan sendiri materi tersebut. Di samping itu, model pembelajaran kontekstual juga mendorong anak untuk menemukan hubungan antara materi yang dipelajarinya dengan kehidupan nyata artinya anak dituntut untuk dapat menangkap hubungan antara pengalaman di sekolah dengan kehidupan nyata. Materi model pembelajaran kontekstual bukan hanya untuk ditumpuk di otak lalu kemudian dilupakan, melainkan dijadikan bekal dalam mengarungi kehidupan nyata. Sesuai dengan pendapat Nurhadi (dalam Muslich, 2011:41) menyatakan bahwa "Model pembelajaran kontekstual terjadi apabila anak menerapkan dan mengalami apa yang sedang diajarkan dengan mengacu pada masalah- 
masalah dunia nyata yang berhubungan dengan peran dan tanggung jawab mereka sebagai anggota keluarga warga negara, siswa dan tenaga kerja".

Lain halnya dengan pembelajaran kelompok eksperimen, kegiatan pembelajaran yang berlangsung pada kelompok kontrol yang masih kurang optimal. Hal ini dikarenakan pembelajaran hanya berpusat pada guru atau dengan kata lain, guru hanya sebagai sumber ilmu dan pemberi informasi. Secara teoritis, pembelajaran yang tidak menggunakan model pembelajaran kontekstual adalah pembelajaran metode ceramah, karena sejak dulu metode ini telah dipergunakan sebagai alat komunikasi lisan antara guru dengan anak dalam proses belajar dan mengajar. Dengan pembelajaran seperti itu membuat anak mudah jenuh, bosan dan mengantuk. Selain itu, keadaan anak-anak pada saat proses pembelajaran berlangsung terlihat kurang aktif jika dibandingkan dengan kelompok eksperimen. Dalam hal ini, terlihat bahwa pembelajaran kurang maksimal dalam meningkatkan kemampuan membaca permulaan anak.

Dengan demikian penelitian ini membuktikan bahwa model pembelajaran kontekstual memberikan pengaruh terhadap kemampuan membaca permulaan anak. Tentu saja dalam hal ini kemampuan membaca permulaan anak meningkat. Hal ini dapat dilihat dari pembelajaran kontekstual lebih banyak menekankan keterlibatan anak dalam menemukan pengetahuan secara nyata yang berada di lingkungan sekitarnnya.

Implikasi dalam penelitian ini yaitu pemilihan dengan menggunakan model pembelajaran yang cocok untuk mempengaruhi kemampuan membaca permulaan anak, sehingga menyebabkan adanya perbedaan pengaruh kemampuan membaca permulaan anak kelompok B TK Gugus I Kecamatan Kuta Selatan 2018/2019.

Pada model pembelajaran kontekstual yang disebabkan mendapatkan perlakuan dan tidak mendapatkan perlakuan. Anak yang dibelajarkan dengan mengikuti model pembelajaran kontekstual dengan anak yang tidak dibelajarkan dengan model pembelajaran kontekstual. Adanya perbedaan pengaruh ini ditindak lanjuti dengan memberikan perbaikan yang diharapkan guru dalam memberikan pembelajaran dapat menggunakan model-model pembelajaran yang inovatif sehingga dapat menciptakan suasana pembelajaran yang lebih berrinovasi. Jadi anak akan menjadi lebih bersemangat dalam mengikuti kegiatan pembelajaran yang nantinya akan berpengaruh pada peningkatan kemampuan membaca permulaan anak.

\section{Simpulan dan Saran}

Permasalahan dalam penelitian ini yaitu untuk meningkatkan kemampuan membaca permulaan anak dengan menggunakan model pembelajaran kontekstual. Tujuan dalam penelitian ini, untuk mengetahui perbedaan yang signifikan antara kelompok anak yang memperoleh pengajaran dengan model pembelajaran kontekstual dengan kelompok anak yang tidak memperoleh pengajaran dengan model pembelajaran kontekstual terhadap kemampuan membaca permulaan anak kelompok B. Adapun manfaat penelitian dapat dibagi menjadi dua yaitu, manfaat teoretis yaitu sebagai pengetahuan awal guru dalam memberikan gambaran yang jelas tentang pengaruh pembelajaran kontekstual terhadap kemampuan membaca permulaan anak, dan manfaat praktis untuk kemudahan bagi siswa, guru, kepala sekolah, dan penelitian lainnya dalam proses pembelajaran dan penelitian lain dalam menggunakan model pembelajaran kontekstual.

Berdasarkan hasil pengujian hipotesis dan pembahasan, maka temuan dalam penelitian ini menyatakan bahwa terdapat perbedaan yang signifikan antara kelompok anak yang memperoleh pengajaran dengan model pembelajaran kontekstual dengan kelompok anak yang tidak memperoleh pengajaran dengan model pembelajaran kontekstual terhadap kemampuan membaca permulaan anak kelompok B di Taman Kanak-kanak Gugus I Kecamatan Kuta Selatan Tahun pelajaran 2018/2019. Hasil analisis menunjukkan bahwa, $t_{\text {hitung }}=12,586$ untuk $\mathrm{db}=34$ pada taraf signifikansi 5\% adalah 2,042. 
Berdasarkan kriteria pengujian, terdapat perbedaan yang signifikan antara kelompok anak yang memperoleh pengajaran dengan model pembelajaran kontekstual dengan kelompok anak yang tidak memperoleh pengajaran dengan model pembelajaran kontekstual terhadap kemampuan membaca permulaan anak.

Maka dapat disimpulkan bahwa pembelajaran dengan model pembelajaran kontekstual berpengaruh positif terhadap kemampuan membaca permulaan anak kelompok B di Taman Kanak-kanak Gugus I Kecamatan Kuta Selatan Tahun pelajaran 2018/2019.

Saran yang dapat disampaikan berdasarkan penelitian yang telah dilakukan adalah sebagai berikut: Pemerintah terkait, khususnya Dinas Pendidikan Nasional agar sering dilaksanakan Pendidikan dan Latihan (Diklat) dalam kaitannya dengan pengembangan Media Pembelajaran maupun Metode Pengajaran, sehingga mutu peserta didik dan pendidik dapat meningkat sesuai dengan apa yang kita harapkan semua, Kepala sekolah hendaknya menjadi fasilitator maupun motivator untuk pendidik dan peserta didik berupa pengadaan sarana dan prasarana, yang mendukung terciptanya prestasi atau tujuan belajar yang diharapkan, Para pendidik perlu menerapkan pembelajaran kontekstual untuk meningkatkan kemampuan membaca anak, Peneliti lain supaya mempersiapkan waktu yang lebih banyak dan mengkaji faktor-faktor yang berpengaruh kepada kemampuan membaca permulaan anak secara lebih mendalam dan Wali murid agar selalu memperhatikan dan memberikan dorongan kepada putra-putrinya agar kemampuan membaca anak-anaknya berkembang.

\section{Daftar Pustaka}

Agung, A, A, Gede. 2014. Metodelogi Penelitian Pendidikan. Malang: Aditya Media Publising.

Ali Mudlofir, Haji. 2017. Desain Pembelajaran Inovatif: Dari Teori ke Praktik. Jakarta: Rajawali Pers.

Antara, Putu Aditya. 2018. Pengaruh Model Pembelajaran Contextual Teaching And Learning (CTL) Terhadap Kemampuan Pengukuran Anak Taman Kanak kanak. EJournal PAUD Undiksha, Volume 6, Nomor 1.

Antara, Putu Aditya. 2019. Implementasi Pengembangan Karakter Anak Usia Dini Dengan Pendekatan Holistik. Jurnal IImiah VISI PGTK PAUD dan Dikmas, Volume 14, Nomor 1 (hal.17-19)

Antara, Putu Aditya. 2018. Pengaruh Pendekatan Fonik Terhadap Kemampuan Membaca Awal Pada Anak Kelompok B. EJournal PAUD Undiksha, Volume 6, Nomor 2.

Aulina, Choirun Nisa. 2012. Pengaruh Pemainan dan Pengusaan Kosakata Terhadap Kemampuan Membaca Permulaan Anak Usia 5-6 Tahun. Pedagogia, Volume 1 Nomor 2. Sidoarjo: Universitas Muhammadiyah Sidoarjo.

Aqib, Zainal. 2013. Model-Model, Media, dan Strategi Pembelajaran Kontekstual (Inovatif). Bandung: Yrama Widya.

Morrisan. 2012. Metode Penelitian Survei. Jakarta: PRENADAMEDIA GROUP.

Nana Syaodih Sukmadinata. 2015. Metode Penelitian Pendidikan. Bandung: PT. Remaja Rosdakarya Offset.

Ningrum, Epon. 2009. Pendekatan Kontekstual. Karawang: RSBI

Noor, Juliansyah. 2011. Metodelogi Penelitian: Skripsi, Tesis, Disertasi dan Karya IImiah. Jakarta: PRENADAMEDIA GROUP. 
Rusman. 2014. Model- model Pembelajaran. Jakarta: PT raja Grafindo.

Setiawati, Putu Ayu Sri. 2018. "Pengaruh Model Pembelajaran Quantum Learning Terhadap Kemampuan Membaca Permulaan Anak Kelompok B Di Gugus VIr'. EJournal PAUD Undiksha, Volume 6, Nomor 2.

Sugiyanto. 2010. Model - Model Pembelajaran Inovatif. Surakarta: Yurma Pustaka. 